\title{
Kondisi Mangrozoobentos Pada Substrat Dasar di Kawasan Ekowisata Desa Pasir, Kabupaten Mempawah
}

\author{
Unggul Pamenang $^{1 *}$, Apriansyah ${ }^{1}$, Yusuf Arief Nurrahman ${ }^{1}$ \\ 1 Program studi Ilmu Kelautan, FMIPA, Universitas Tanjunpura, Pontianak- \\ Indonesia \\ *Correspondence email: Unggul Pamenang \\ $\triangle$ hardcorenanang@gmail.com
}

\section{Received:17 December 2018- Accepted: 08 February 2019 \\ Published: 31 October 2019 (C) Author(s) 2019. This article is open access}

\begin{abstract}
Tujuan dari penelitian ini adalah mengetahui keadaan makrozoobentos di kawasan ekowisata Desa Pasir, Kabupaten Mempawah. Variabel yang diteliti meliputi tekstur sedimen, kandungan bahan organik, kelimpahan makrozoobentos dan parameter perairan. Selanjutnya dianalisis menggunakan analisis deskriptif. Hasil penelitian ditemukan 5 famili dari 3 kelas makrozoobentos, dengan kelimpahan berkisar 36,5 - 128,4 ind/m2. Kondisi perairan kawasan ekowisata Desa Pasir masih tergolong layak untuk kehidupan makrozoobentos, akan tetapi memiliki kandungan bahan organik yang tergolong tinggi. Berdasarkan penelitian dapat disimpulkan makrozoobentos di lokasi penelitian berada di lingkungan yang sesuai untuk kehidupan makrozoobentos dengan persentasi fraksi lanau lebih dominan dibandingkan fraksi pasir dan lempung.
\end{abstract}

Keywords: Makrozoobentos, Mempawah, substrat dasar

\section{Pendahuluan}

Kawasan pesisir dapat didefinisikan sebagai daerah peralihan karena letaknya yang berbatasan antara darat dan laut. Muhaimin (2013), Mengatakan bahwa kawasan yang berbatasan antara darat dan laut menjadi kawasan yang mudah mengalami perubahan. Perubahan yang terjadi juga berpengaruh terhadap biota yang hidup di kawasan tersebut.

Biota yang hidup di kawasan pesisir pada umumnya adalah makrozoobentos. Keberadaan makrozoobentos memiliki peranan dalam rantai makanan dan dapat menjadi indikator kualitas lingkungan. Pergerakan dari makrozoobentos yang lambat dan cara hidup makrozoobentos yang cenderung menetap menjadikan makrozoobentos peka terhadap perubahan lingkungan yang terjadi.

Substrat berperan sebagai habitat hidup makrozoobentos. Substrat dapat mempengaruhi susunan komunitas makrozoobentos yang terdapat didalamnya.

Menurut Putri et al., (2016), substrat memiliki keterkaitan yang sangat kuat dan dapat mempengaruhi kelimpahan makrozoobentos. Semakin besar persentase substrat lempung akan diiringi dengan bertambahnya kandungan bahan organik dan melimpahnya makrozoobentos (Putri et al., 2016). 
Kawasan ekowisata Desa Pasir, berada di Kabupatan Mempawah, Provinsi Kalimantan Barat. Selain sebagai kawasan wisata kawasan tersebut juga merupakan kawasan rehabilitasi mangrove. Sehingga informasi mengenai makrozoobentos dan substrat dasar dapat menjadi sangat penting dalam menentukan pengelolaan kawasan tersebut.

\section{Metode}

\subsection{Waktu dan tempat}

Penelitian dilakukan di kawasan ekowisata, Desa Pasir, Kabupaten Mempawah, Kalimantan Barat (Gambar 1). Penentuan stasiun dilakukan dengan metode purposive sampling, yaitu dengan mempertimbangkan bahwa masing-masing stasiun dapat mewakili dari daerah penelitian.

\subsection{Pengambilan Makrozoobentos}

Makrozoobentos diambil menggunakan sedimen grab (Michael, 1994), kemudian disaring menggunakan slave net berukuran $1 \mathrm{~mm}$. Makrozoobentos yang tertahan pada shave net diambil, kemudian sampel diawetkan dengan alkohol 70\%. Makrozoobentos yang diperoleh identifikasi hingga tingkatan famili menggunakan buku identifikasi dari FAO.

Untuk mengetahui kelimpahan makrozoobentos menggunakan persamaan menurut (Odum, 1971 dalam Muhaimin, 2013):

$K=\frac{10000 \times a}{b}$
Keterangan:

$\mathrm{K}:$ Kelimpahan makrozoobentos (ind $/ \mathrm{m}^{2}$ )

a : Jumlah makrozoobentos (ind)

b : Luas bukaan sedimen grab $\left(\mathrm{cm}^{2}\right)$

\subsection{Analisis Data}

\subsubsection{Analisis Substrat Dasar}

Pengambilan sampel substrat dilakukan pada setiap plot, menggunakan sedimen grab yang berukuran 33 x $33 \mathrm{~cm}$. Sampel yang diperoleh dimasukkan ke dalam plastik sampel untuk diuji di laboratorium. Substrat dasar yang diperoleh dianalisa dengan metode ayakan basah. Tahap pertama dilakukan uji hydrometer, dan tahap kedua yaitu pengujian berat jenis untuk mendapatkan persentase tekstur sedimen.

\subsubsection{Penentuan Bahan Organik}

Penentuan bahan organik dimulai dengan mengeringkan sampel, kemudian ditumbuk dan diayak menggunakan saringan $2 \mathrm{~mm}$. Selanjutnya ditimbang cawan porselen, kemudian ditambahkan sampel sebanyak \pm 3 $\mathrm{g}$, Lalu sampel ditanur dengan suhu \pm 500-600 ${ }^{0} C$ selama $\pm 6-7$ jam, tujuan sampel ditanur adalah supaya bahan organik dapat terurai, selanjutnya dihitung kadar abu (berat setelah ditanur - berat cawan). Kemudian dihitung persentase bahan organik sampel.

Perhitungan persentase kandungan bahan organik sampel dihitung dengan:

$\%$ bahan organik $=($ Berat awal - kadar abu /berat awal sedimen $) \times 100 \%$

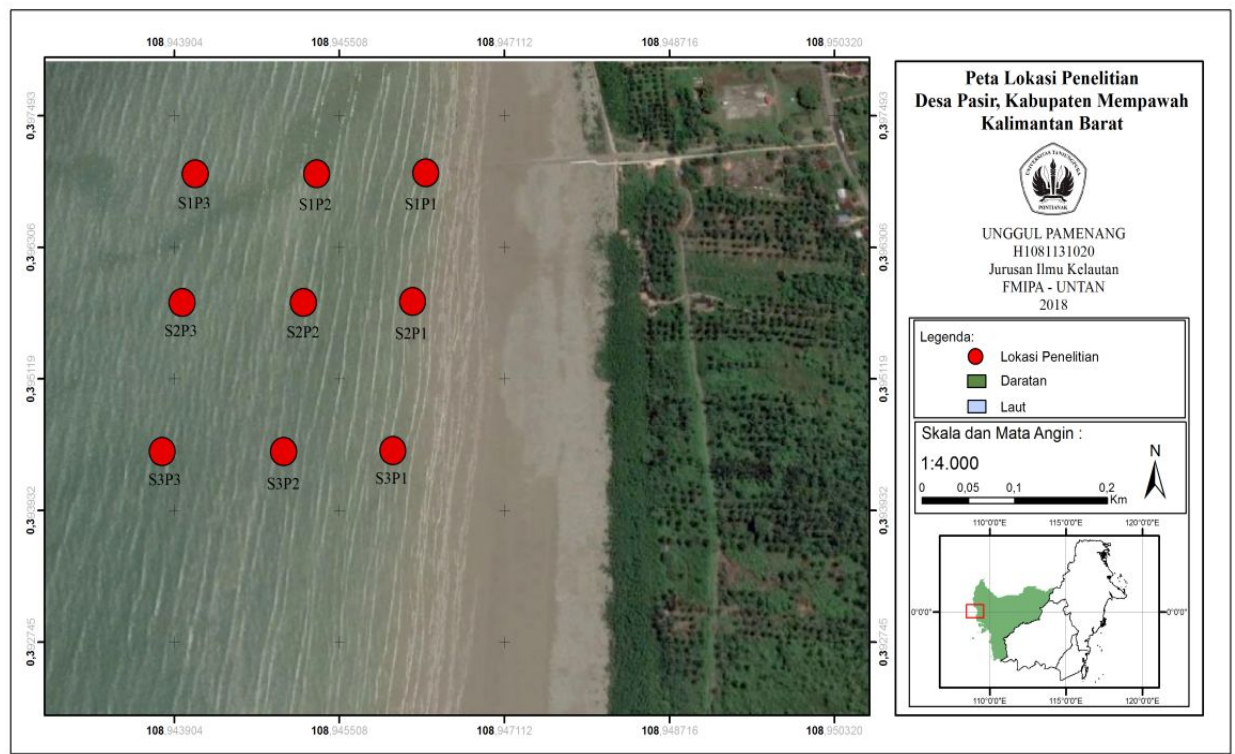

Gambar 1. Peta lokasi penelitian 


\subsubsection{Parameter Perairan}

Parameter perairan yang diambil meliputi: Kecepatan arus, salinitas, suhu air dan derajat keasaman $(\mathrm{pH})$ air (Riniasih and Kushartomo, 2009). Penentuan kecepatan arus menggunakan persamaan:

$v=\frac{s}{t}$

Keterangan:

$\mathrm{v}=$ Kecepatan $\operatorname{arus}(\mathrm{m} / \mathrm{s})$

$\mathrm{s}=$ Jarak tempuh layang-layang arus (m)

$\mathrm{t}=$ Waktu tempuh (detik)

\section{Hasil dan Pembahasan}

\subsection{Komposisi jenis dan kelimpahan} Makrozoobentos

Jenis makrozoobentos di kawasan ekowisata Desa Pasir terdiri 2 famili (Bivalvia, Polychaeta, dan Gastropoda), dan 5 famili. Kelas Bivalvia terdiri atas 2 famili (Veneridae dan Corbulidae), Kelas Polychaeta terdiri atas 2 famili (Glyceridae dan Lumbrineridae), dan kelas Gastropoda terdiri atas 1 famili (Nassariidae).

Keberadaan makrozoobentos pada setiap stasiun penelitian (Tabel 1) ditemukan masing - masing 3 famili makrozoobentos dengan 2 famili (Veneridae dan Glyceridae) berada di semua stasiun penelitian. Stasiun 1 ditemukan famili Veneridae, Glyceridae, dan Lumbrineridae, stasiun 2 ditemukan famili Veneridae, Corbulidae, dan Glyceridae, dan stasiun 3 ditemukan famili Veneridae, Glyceridae, dan Nassariidae.
Keberadaan makrozoobentos yang ditemukan pada setiap stasiun berasal dari kelas Bivalvia dan Polychaeta. Hal ini dikarenakan kemampuan adaptasi yang tinggi dari kedua kelas makrozoobentos tersebut. Seperti pernyataan Yunitawati (2012) yang menyatakan Bivalve dapat hidup ditempat dengan bahan organik tinggi, dan Wahyuningrum et al,. (2016), yang menyatakan bahawa Polychaeta memiliki tingkat adaptasi yang tinggi di suatu lingkungan.

Seperti yang ditunjukan (Tabel 2) kelimpahan makrozoobentos ditemukan kelimpahan tertinggi di stasiun 2 dengan nilai 128,4 individu $/ \mathrm{m}^{2}$. Hal ini dapat disebabkan karena substrat dasar di stasiun 2 memiliki fraksi pasir yang lebih tinggi dari stasiun lainnya, dan juga kandungan bahan organik yang lebih rendah dari stasiun lainnya. Hal ini sama seperti pernyataan Muhaimin (2013), yang menyatakan makrozoobentos seperti Bivalve lebih mendominasi pada tekstur pasir dan pernyataan Sudaryanto (2001), yang mengatakan tingginya kandungan bahan organik dapat menurunkan kelimpahan makrozoobentos.

\subsection{Kondisi lingkungan perairan}

Kondisi lingkungan perairan kawasan (Tabel 3) ekowisata Desa Pasir didapat kecepatan arus berkisar $0,0321-0,9166 \mathrm{~m} / \mathrm{s}$. Salinias berkisar 23,5 - 25 ppt. Suhu berkisar 29,6 32,75 0C. pH berkisar 7,76-8,165. Bahan organik rata-rata pada setiap stasiun berkisar

Tabel 1. Keberadaan makrozoobentos di lokasi penelitian

\begin{tabular}{lccc}
\hline \multirow{2}{*}{ Makrozoobentos } & \multicolumn{3}{c}{ Stasiun } \\
& I & II & III \\
\hline Bivalvia & & & \\
Veneridae & + & + & + \\
Corbulidae & - & + & - \\
Polychaeta & & & \\
Glyceridae & + & + & + \\
Lumbrineridae & + & - & - \\
Gastropoda & & & \\
Nassariidae & - & - & + \\
\hline Total $\quad(+)=$ Ada & \multicolumn{2}{c}{3} & 3 \\
\hline Ket $:$ & \multicolumn{2}{c}{ Tidak Ada }
\end{tabular}


Tabel 2. Kelimpahan makrozoobentos di lokasi penelitian

\begin{tabular}{lcccccc}
\hline \multirow{2}{*}{ Famili } & \multicolumn{9}{c}{ Stasiun } \\
& \multicolumn{1}{c}{ I } & \multicolumn{2}{c}{ II } & \multicolumn{2}{c}{ III } \\
& K & KR & K & KR & K & KR \\
\hline Bivalvia & & & & & & \\
Veneridae & 18,3 & 50,1 & 101 & 78,7 & 27,5 & 60,2 \\
Corbulidae & 0 & 0 & 18,3 & 14,3 & 0 & 0 \\
\hline Polychaeta & & & & & & \\
Glyceridae & 9,1 & 24,9 & 9,1 & 7,1 & 9,1 & 19,9 \\
Lumbrineridae & 9,1 & 24,9 & 0 & 0 & 0 & 0 \\
\hline Gastropoda & & & & & & \\
Nassariidae & 0 & 0 & 0 & 0 & 9,1 & 19,9 \\
\hline Jumlah & 36,5 & 100 & 128,4 & 100 & 45,7 & 100 \\
\hline \multicolumn{1}{c}{ K: Kelim } & & &
\end{tabular}

K: Kelimpahan makrozoobentos (ind $/ \mathrm{m} 2$ )

KR: Kelimpahan Relatif

Tabel 3. Nilai parameter ketiga stasiun

\begin{tabular}{|c|c|c|c|c|c|c|c|c|c|}
\hline \multirow[t]{2}{*}{ St } & \multirow[t]{2}{*}{ Plot } & \multirow[t]{2}{*}{$\begin{array}{l}\text { V Arus } \\
\text { (m/detik) }\end{array}$} & \multirow[t]{2}{*}{$\begin{array}{c}\text { S } \\
\text { (ppt) }\end{array}$} & \multirow[t]{2}{*}{$\begin{array}{c}\mathrm{T} \\
\left({ }^{\circ} \mathrm{C}\right)\end{array}$} & \multirow[t]{2}{*}{ pH } & \multirow{2}{*}{$\begin{array}{c}\text { Bahan } \\
\text { Organik } \\
(\%)\end{array}$} & \multicolumn{3}{|c|}{$\begin{array}{c}\text { Pesentase } \\
\text { Substrat }\end{array}$} \\
\hline & & & & & & & $\mathrm{Pa}$ & La & Le \\
\hline \multirow{3}{*}{ I } & 1 & 0,2135 & 24 & 29,6 & 7,76 & 17 & 7 & 51 & 42 \\
\hline & 2 & 0,2451 & 23,5 & 31,3 & 8,09 & 16,33 & 7 & 52 & 41 \\
\hline & 3 & 0,1781 & 25 & 32,6 & 8,04 & 20,40 & 8 & 55 & 37 \\
\hline \multirow{3}{*}{ II } & 1 & 0,1451 & 24 & 30,05 & 7,86 & 20 & 6 & 52 & 42 \\
\hline & 2 & 0,9166 & 23,5 & 31,15 & 8,02 & 14,24 & 14 & 53 & 33 \\
\hline & 3 & 0,1590 & 24 & 32,05 & 8,13 & 19,33 & 11 & 51 & 38 \\
\hline \multirow{3}{*}{ III } & 1 & 0,0321 & 24 & 30,5 & 7,85 & 18,03 & 8 & 55 & 37 \\
\hline & 2 & 0,0787 & 24 & 32 & 8,07 & 18,60 & 6 & 50 & 44 \\
\hline & 3 & 0,2086 & 23,5 & 32,75 & 8,17 & 17,94 & 11 & 53 & 36 \\
\hline
\end{tabular}

St: Stasiun; Pa : pasir; La: Lanau; Le: Lempung

17,86 - 18,19 persen dan untuk persentase substrat dasar fraksi lanau lebih mendominasi dibandingkan fraksi pasir dan lempung.

Kondisi perairan memiliki pengaruh langsung maupun tidak langsung terhadap makrozoobentos. Secara umum hasil pengukuran kondisi lingkungan perairan kawasan ekowisata Desa Pasir masih layak untuk kehidupan makrozoobentos.

Kecepatan arus yang tinggi dapat menyebabkan substrat tempat hidup makrozoobentos mudah bergerak. Kecepatan arus yang didapat dalam penelitian tergolong arus dengan kecepatan sangat lambat hingga cepat. Menurut Yunitawati et al., (2012) kecepatan arus $<0,1 \mathrm{~m} /$ detik tergolong arus sangat lambat dan $0,5-1 \mathrm{~m} /$ detik tergolong arus cepat. Seperti arus yang terdapat stasiun 2 plot 2 yang memiliki arus tergolong cepat dengan kecepatan arus $0,9166 \mathrm{~m} /$ detik.

Suhu dapat mempengaruhi metabolisme makrozoobentos, suhu yang didapat dalam penelitian termasuk yang sesuai untuk mendukung kehidupan makrzoobentos. Hal ini sesuai pernyataan Zulfiandi et al., (2012) yang menyatakan kisaran suhu 26,9 - 33,4 ${ }^{0} \mathrm{C}$ masih tergolong normal bagi kehidupan makrozoobentos.

Salinitas memiliki mempengaruhi daya kelangsungan hidup biota perairan termasuk makrozoobentos. Salinitas yang diamati selama penelitian termasuk sesuai untuk kelangsungan hidup makrozoobentos. Menurut Zulfiandi et al., (2012), kisaran 
salinitas $21-33,3$ ppt tergolong layak untuk kehidupan biota laut.

Nilai $\mathrm{pH}$ pada suatu perairan dapat menunjukan sifat perairan tersebut, hasil pengamatan $\mathrm{pH}$ yang dilakukan selama penelitian menunjukan $\mathrm{pH}$ bersifat alkali dan masih dapat mendukung kehidupan makrozoobentos. Hal ini sesuai dengan pernyataan Yunitawati et al., (2012) pada $\mathrm{pH}$ 8,54 masih terdapat makrozoobentos.

Yuningsih et al., (2014) menyatakan bahan organik yang terlalu tinggi mengakibatkan organisme pengurai mudah berkembang dan membutuhkan oksigen terlarut dalam proses penguraiannya. Penelitian ini memiliki kandungan bahan organik tinggi sebesar $17-35 \%$, hal ini berdasarkan penyataan Radojevic dan Bashkin, (1999) yang mengkriteria kandungan bahan organik termasuk dalam kriteria tinggi.

Putri et al., (2016) menyatakan substrat dasar memiliki keterkaitan yang sangat kuat dan mempengaruhi kelimpahan makrozoobentos. Hasil analisis substrat dasar yang dilakukan, didapatkan persentase fraksi lanau lebih mendominasi dibandingkan fraksi pasir dan lempung.

\section{Kesimpulan}

Makrozoobentos yang didapatkan terdiri dari Kelas Bivalvia terdiri atas 2 famili (Veneridae dan Corbulidae), Kelas Polychaeta terdiri atas 2 famili (Glyceridae dan Lumbrineridae), dan kelas Gastropoda terdiri atas 1 famili (Nassariidae) dengan nilai kelimpahan makrozoobentos tertinggi 128,4 individu $/ \mathrm{m}^{2}$. Secara umum kondisi perairan kawasan ekowisata Desa Pasir masih layak untuk kehidupan makrozoobentos dengan persentase substrat didominasi fraksi lanau.

\section{Daftar Pustaka}

Michael, P. 1994. Metode Ekologi Untuk Penyelidikan Ladang dan Laboratorium. Jakarta: UI Press.

Muhaimin, H. 2013. Distribusi Makrozoobentos Pada Sedimen Bar (Pasir Penghalang) Di Intertidal Pantai Desa Mappakalompo Kabupaten Takalar. Skripsi. Universitas Hasanuddin, Fakultas Ilmu Kelautan Dan Perikanan, Makassar.

Odum, E.P. 1971. Dasar-Dasar Ekologi. Yogyakarta: Gajah Mada University Press.

Putri, A.M.S., Suryati, dan N. Widyorini. 2016. Hubungan Tekstur Sedimen dengan Kandungan Bahan Organik dan Kelimpahan
Makrozoobentos di Muara Sungai Banjir Kanal Timur Semarang, Saintek Perikanan. 12 (1).

Radojevic, M., and V.N. Bashkin. 1999. Practical Environmental Analysis. ---: Chambridge. Published The Royal Society of Chemistry.

Riniatsih, I. and E.W. Kushartomo. 2009. Substrat Dasar Dan Parameter Oseanografi Sebagai Penentu Keberadaan Gastropoda Dan Bivalvia Di Pantai Sluke Kabupaten Rembang. Ilmu Kelautan. 14(1).

Sudaryanto, A. 2001. Struktur Komunitas Makrozoobenthos Dan Kondisi Fisiko Kimiawi Sedimen Di Perairan Donan, Cilacap - Jawa Tengah. Jurnal Teknologi Lingkungan. 2(2).

Wahyuningrum, E.S., M.R. Muskananfola, and A. Suryanto. 2016. Hubungan Tekstur Sedimen, Bahan Organik Dengan Kelimpahan Biota Makrozoobentos Di Perairan Delta Wulan, Kabupaten Demak. Management Of Aquatic Resources. 5 (1).

Yuningsih, H.D., P. Soedarsono, and S. Anggoro. 2014. Hubungan Bahan Organik Dengan Produktivitas Perairan Pada Kawasan Tutupan Eceng Gondok, Perairan Terbuka Dan Keramba Jaring Apung Di Rawa Pening Kabupaten Semarang Jawa Tengah. Management Of Aquatic Resources. 3(1).

Yunitawati, Sunarto, and Z. Hasan. 2012. Hubungan Antara Karakteristik Substrat Dengan Struktur Komunitas Makrozoobentos Di Sungai Cantigi, Kabupaten Indramayu, Jurnal Perikanan Dan Kelautan. 3(3).

Zulfiandi, M. Zainuri, and R. Hartati. 2012. Struktur Komunitas Makrozoobentos di Perairan Pandansari Kecamatan Sayung Kabupaten Demak. Journal of Marine Research. 1(1). 